\title{
Analysis of Elections Using Social Listening in Japan
}

\author{
Hisaki Goto \\ Kyushu Sangyo University \\ profgoto@me.com
}

\author{
Yukiko Goto \\ Enconnect Co., Ltd. \\ kizuki.yukiko@gmail.com
}

\begin{abstract}
An "Obama-style" election campaign that utilizes social media has now spread and is actively used all over the world. In Japan, however, Internet campaigning was not available until 2013, and even after the ban on Internet campaigning was lifted, campaigning structure cannot fully utilize social media due to regulations. On the other hand, since social media are enthusiastically used in Japan, social listening, through which information is gathered in a spontaneous manner, is useful. During the national election in 2016, 1,777,724 of postings containing political party names were collected, and results predictions were successfully made. This study analyzes national elections in Japan using social listening, where predictions were successfully made in the proportional representative electoral system.
\end{abstract}

\section{Introduction}

During the U.S. presidential election in 2008, election campaign methods that focused more on the Internet than on conventional media, attracted considerable attention. The notable key to the victory of Barack Obama in the presidential election was, as Maejima (2011) noted, a systematic coordination between vertical communication using an official campaign website and Twitter, the supporters' horizontal mutual support structure through the candidate's Social Networking Service, and anonymous support groups who voluntarily write blogs [1]. Since then this Internet-utilizing "Obama-style" campaign has been having a huge influence on election campaigns in the U.S. As Gordon (2010) reports, the "Obama-style" election campaign was enthusiastically adopted during the United Kingdom's general election in May $2010^{[2]}$, and has been spreading all over the world.

However, Japan had to wait, due to traditional regulations, until the $23^{\text {rd }}$ Upper House regular election held in July 2013, when the Internet was first allowed to be used for election campaigns.

This study analyzes national elections in Japan (the $23^{\text {rd }}$ Upper House regular election, the $47^{\text {th }}$ Lower House general election, and the $24^{\text {th }}$ Upper House general election) using social listening.

\section{Social Listening}

Social Listening means to collect and analyze a large amount of information posted on social media to make use of it for problem solving. In this chapter the significance of social listening and the current state of social media in Japan are discussed.

\subsection{What is Social Listening?}

As Goto (2012) describes, it is possible, for example, to find reasons from Point Of Sale data or customer data as to why customers purchased certain products, but it is difficult to find reasons why customers did not choose said products. Also, although acquiring negative information is possible from complaints or suggestions collected at customer service departments or call centers for product improvement, it is difficult to include positive information from satisfied customers for overall analysis. However, social listening makes it possible to collect both positive and negative information together ${ }^{[3]}$. Through social listening it is possible to collect massive data that was not available previously (Takeda et al. 2012. calculates that the volume of messages a middle-sized call center accumulates throughout a year can be collected in a day ${ }^{[4]}$ ), and with that prospect social listening plays an important role in the business world. In short, under the conventional method, marketing research is conducted by gathering information at the scene or by survey using a certain number of samples for product development, marketing and management as shown in Figure 1. In contrast, social listening makes it possible for companies to listen to numerous opinions from consumers and society through SNS as shown in Figure 2; as a result consumers and society 
can be put in the center for product development, marketing and management. The merit of social listening is that straightforward opinions from consumers or citizens, who evaluate the quality of products, services or policies, can be heard. However, since the receivers of those opinions are generally consumers or citizens, opinions tend to be rather stereotypical and do not provide enterprises with innovative ideas.

This study analyzes Japan's election campaigns using social listening that has been used primarily for marketing research.

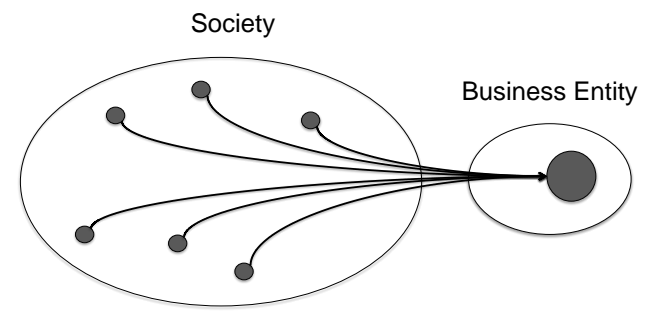

Figure 1. Information gathering structure by business entity

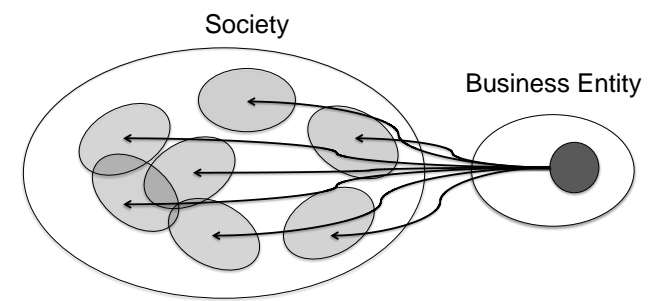

Figure 2. Information gathering structure by social media

\subsection{Social Media in Japan}

A social network service that holds the largest number of accounts in Japan (total population $126,937,000$ as of November 1, 2016) is LINE with 68 million users, followed by Twitter and Facebook with 40 million and 27 million users respectively ${ }^{[5]}$. However, LINE could be called a closed social media because LINE is to exchange messages between friends and family members, and the size of the network is quite small compared to Twitter. (LINE is basically a text-chat application like Messenger in Facebook, and communications are made between friends or a group only. Therefore, LINE is sometimes not considered an SNS application; however, the Ministry of Public Management, Home Affairs, Posts and Telecommunications reported in the White Paper Information and Communications in 2015 that "although LINE is often considered a messaging application or a call application, it is classified as an SNS application considering its widespread use", and also noted that the LINE population is vastly different depending on ages; more than $60 \%$ of those age twenty or under are using LINE, whereas the use of LINE by those age 60 or over is less than $1 \%$. In addition, the data by the Association for Promoting Fair Election in 2016 shows that the voting rate decreases with age; the highest voter turnout age group is the 60 's, which is $68.28 \%$, and that of the 20's is $32.58 \%$. The Association did not disclose LINE data; thus those data were not subject to the research (the number of LINE users was described in the research)). Thus, Twitter and Facebook are appropriate for this study.

The world record for the number of tweets per minute is 618,725 tweets right after the match between Argentina versus Germany during the 2014 Soccer World Cup, and the world record for the number of tweets per second is 143,199 during the Japanese animated adventure film "Laputa: Castle in the Sky" broadcast on August 2nd in 2013. In addition, Japan dominates high ranking positions in the number of tweets per second. Twitter Inc. portrays Japan's love of Twitter as "insane" [6].

\section{Internet Campaigning in Japan}

This section summarizes the legal and legislative history of Internet election campaigning in Japan, the limits on constructing an "Obama-style" campaign under the current circumstances, and the distinctive position of this study by comparing it with previous studies that used social media for analyses of election campaigns.

\subsection{Summary of Legal and Legislative History of Internet Campaigning in Japan}

The Internet election campaigns in Japan became available through "The Act for Amending Part of the Public Offices Election Law related to Permission for Internet Election Campaigns" which was passed on April 19, promulgated on April 26, and implemented on May 26, 2013. This amendment applies, due to Additional Clause 2, on the day of public announcement of national or local elections after its implementation, and was first applied to the 23rd Upper House regular election announced on July 4, 2013 (The first casting and counting after the internet election was allowed was held on July $14^{\text {th }}$ at the Nakama-city assembly election in Fukuoka, which was announced on July 7). Due to this amendment, election campaigns using social media became available in Japan. The Public Offices Election Law, the 
regulations related to elections in Japan, regulates the distribution of documents and drawings (such as post cards, placards or flyers) through Article 142 to protect the fairness and equality of elections, and a precedent has been established that the contents displayed on computer screens or cell phones are also considered documents or drawings (December 22, 2005 Tokyo High Court, and the appeal was rejected by the Supreme Court and became final and binding on February 16, 2007); therefore, election campaigns using the Internet had not been available.

Also in October 1996 when a political party "New Party Sakigake" made an inquiry with the Ministry of Home Affairs (currently the Ministry of Internal Affairs and Communications) into an official interpretation of Internet campaigning, the response was that the contents displayed on computer screens or cell phones are considered documents or drawings.

However, in October 2001 a study group to discuss election campaigns in the IT era was formed, and the effects, issues and opinions on Internet campaigning were reported in August 2002. After much debate, "The Act for Amending Part of the Public Offices Election Law related to Permission for Internet Election Campaigns" was passed in 2013.

This amendment made it possible for candidates and voters to perform election campaigns using the Internet (by creating a homepage, writing a blog post, using SNS, webcasting policy). However, the use of emails for campaigning is allowed for political parties and candidates but not for voters. The reasons for excluding voters are 1) voters' e-mails might be abused or lead to identity thefts 2) the high possibility of voters being punished and facing suspension of civil rights due to complicated transmission regulations 3) the excessive burden on voters caused by virus infections on devices.

Due to the reasons described earlier there is a limit on Internet campaigning in Japan which makes it difficult to form the "Obama-style" campaign structure.

\subsection{Analysis of Elections by Social Media}

With the debut of the "Obama-style" election campaign, the analysis of elections focusing on social media appeared in various countries, including the studies focusing on Tweets by Andranik T. et al $(2010)^{[7]}$ and Andreas J. et al (2012) ${ }^{[8]}$. Andranik T. et al (2010) analyzed a German Federal Diet election from 100,000 tweets.

After the ban on Internet campaigning was lifted Nasuno et al. (2013 and 2014) and Yoshimi (2016) published studies focusing on social media to analyze Japanese elections. Nasuno et al. (2013 and 2014) analyzed the 23rd Upper House regular election using 42,645 tweets by 287 candidates and 368,694 of retweets of them ${ }^{[9]}$. Also Yoshimi (2016) targeted 30,941 tweets by 537 candidates running from five major political parties (Japanese Communist Party, Liberal Democratic Party of Japan, Democratic Party of Japan and two other parties) in the $47^{\text {th }}$ Lower House general election $^{[10]}$.

As mentioned above, the structure of Internet campaigning in national elections in Japan is different from the "Obama-style" campaign structure. The structure of the "Obama-style" campaign is a systematic coordination between vertical communication using an official campaign website and Twitter, the supporters' horizontal mutual support structure through the candidate's SNS, and anonymous online support groups who voluntarily write articles in blogs. As the previous three studies by Japanese scholars show, the connection between the vertical and horizontal structures of candidates and voters is weak in Japan, where the number of tweets is extremely low.

However, the Japanese love of Twitter contributes to the creation of anonymous online support groups through Twitter, and this fact calls for the analysis of elections using Twitter. As Goto (2015) noted, although the use of Twitter for analyzing elections in small constituencies was difficult due to the scarce number of tweets containing candidate names, the analysis of tweets that contain party names in the proportional representative (PR) electoral system was valid $^{[11]}$. For the above study 956,268 and 1,287,982 tweets that contained party names were collected during the $23^{\text {rd }}$ Upper House regular election and the $47^{\text {th }}$ Lower House general election respectively. Also, during the 24th Upper House regular election $1,777,724$ tweets were collected, which is an overwhelmingly large volume of data compared to other research performed in Japan or other countries. Showing a research outcome using a large amount of data does not always prove the excellence of a research. However, the studies by Andranik $T$. et al(2010) and Andreas J. et al (2012) show different results, and the studies by Nasuno et al. (2013 and 2014) and Yoshimi (2016) only show a tendency due to the scarce amount of data. In contrast, this study shows the statistical significance by using a large amount of data. The study of differences between the above four studies and ours needs to be pursued, but the amount of data seems to significantly contribute to the outcome. 


\section{Analysis of Japanese National Elections by Social Listening}

Goto (2015) analyzed the $23^{\text {rd }}$ Upper House regular election (announced on July 4 and held on July 21, 2013) and the $47^{\text {th }}$ Lower House general election (announced on December 2 and held on December 14, 2014) using social listening. However, predictions of the results in constituencies for the Upper House election and small constituencies for the Lower House election were not possible due to the scarce number of postings containing the candidate names. Also, for predictions of individual votes in the PR system, social listening was not useful on candidates who focus mainly on organized votes from groups such as large scale industry group, labor union, interest group or religious group. For example, Yoshifumi Takushoku, who earned the largest votes of 429,002 at the $23^{\text {rd }}$ Upper House general election, is a former head of the national association of postmasters and received organized votes from postal businesses in spite that the number of postings containing his name was only 8 .

However, for the party-list votes predictions in the PR system it was proved that social listening was useful and that real-time results predictions were possible as well.

The following are the analysis results of the elections in the PR system for the $23^{\text {rd }}$ and $24^{\text {th }}$ Upper House regular elections and the $47^{\text {th }}$ Lower House general election using social listening. Data for social listening was collected via Yahoo! JAPAN real-time search (Yahoo! JAPAN launched real-time search in June, 2011, and public posting by Facebook became available to search in October, 2012. In order to conduct this study in countries other than Japan, data can be purchased from a company which has a firehose contract with Twitter Inc.). With this real-time search, tweets in the Japanese language that are not set as "private" and Facebook postings that are set as "public" can be searched by minute. Political party names were searched using this search engine.

\subsection{Analysis of the $23^{\text {rd }}$ Upper House Regular Election}

Using social listening focusing on postings that contain party names, 12 registered parties' official names and official abbreviated names were extracted for the $23^{\text {rd }}$ Upper House regular election analysis. Since it was difficult to identify applicable parties in a search by the official abbreviated names of "Your party", "New Party DAICHI", "People's Life Party", "Green Wind", "Green Party" and "Happiness Realization Party" that are "You", "DAICHI", "Life", "Midori (note that 'midori' is the Japanese translation of green), "Green" and "Happiness" respectively, the mean value was calculated after dividing the number of an abbreviated official name identified by the number of official name, and then the mean value $(=0.53)$ (minimum: 0.47 for Liberal Democratic Party of Japan, maximum: 0.65 for Japanese Communist Party) was added to the number of each party's official name on a daily basis during the election campaign.

The results are shown in Table 1 and Figure 3. The data used for social listening during the 17 day campaign period was 956,268 tweets, and the total party-list votes were 39,122,641. As Figure 3 shows, party names that most appeared in the postings were Liberal Democratic Party of Japan (LDP), followed by Democratic Party of Japan (DPJ) and Japan Restoration Party (JRP). Each party's total number posted during the campaign period and the number of party-list votes in the PR system are shown in Table 1. Figure 4 shows the correlation between those two values.

As the Figure number shows R2 is 0.847, and Pearson correlation coefficient is 0.920 which is $1 \%$ level and is significant (both sides); thus a strong correlation between the number of postings that contained a party name and the party-list votes in the PR system is found.

Figure 5 shows, among postings during the campaign, each party's total number posted is proportioned by 48 seats involved in the PR electoral system until a particular date described in the Figure.

Table 1. Each registered party's total number posted during the $23^{\text {rd }}$ Upper House election

\begin{tabular}{|c|c|c|c|c|c|c|c|c|c|c|c|c|c|c|c|c|c|c|c|}
\hline & Jul.4 & Jul.5 & Jul.6 & Jul.7 & Jul. 8 & Jul.9 & Jul.10 & Jul.11 & Jul.12 & Jul.13 & Jul.14 & Jul.15 & Jul.16 & Jul.17 & Jul.18 & Jul.19 & Jul.20 & Total & Nr. of votes \\
\hline YP & 1586 & 2311 & 2102 & 1803 & 1891 & 1534 & 1791 & 1661 & 1767 & 1586 & 2709 & 2132 & 2628 & 2079 & 2171 & 2031 & 2115 & 33,898 & $4,221,422$ \\
\hline DPJ & 7924 & 11024 & 10497 & 12014 & 8863 & 9436 & 9982 & 9652 & 10817 & 8715 & 7595 & 9711 & 12255 & 12352 & 12181 & 11938 & 11357 & 176,313 & $4,827,158$ \\
\hline NPD & 141 & 2744 & 844 & 413 & 327 & 220 & 369 & 327 & 1065 & 427 & 396 & 376 & 710 & 297 & 433 & 353 & 546 & 9,988 & 398,848 \\
\hline SPD & 1683 & 3002 & 1902 & 2957 & 2325 & 1629 & 1809 & 1995 & 1663 & 1459 & 1492 & 1871 & 1516 & 1631 & 1761 & 2088 & 2051 & 32,834 & 983,227 \\
\hline PLP & 1006 & 2701 & 2190 & 2216 & 2128 & 1721 & 1719 & 1912 & 1927 & 2492 & 2405 & 2781 & 2284 & 2499 & 3110 & 3151 & 2714 & 38,956 & 723,987 \\
\hline GW & 970 & 1470 & 1034 & 935 & 899 & 808 & 837 & 849 & 748 & 803 & 1135 & 1426 & 1542 & 1338 & 1276 & 1404 & 1501 & 18,973 & 319,630 \\
\hline LDP & 9577 & 24012 & 33144 & 25220 & 19431 & 17485 & 16506 & 14894 & 15498 & 15643 & 15934 & 18407 & 18437 & 22023 & 30730 & 28149 & 30409 & 355,499 & $14,080,143$ \\
\hline JCP & 1212 & 3348 & 3112 & 3211 & 2971 & 2734 & 2484 & 2815 & 2998 & 2637 & 2446 & 2890 & 3285 & 3372 & 3838 & 4146 & 4726 & 52,225 & $4,647,765$ \\
\hline Komeito & 1285 & 3805 & 3054 & 3311 & 3413 & 2855 & 2457 & 2639 & 2587 & 2334 & 2957 & 3247 & 3752 & 3961 & 4237 & 4325 & 4303 & 54,522 & $3,333,142$ \\
\hline GP & 1144 & 1839 & 2720 & 2010 & 1496 & 1695 & 1733 & 2580 & 2405 & 2591 & 2509 & 2931 & 3647 & 4075 & 3578 & 3556 & 3985 & 44,492 & 242,460 \\
\hline JRP & 2845 & 5463 & 5144 & 5463 & 5786 & 6919 & 6263 & 6220 & 5044 & 6791 & 8591 & 7096 & 5538 & 5897 & 6242 & 6177 & 7023 & 102,502 & $5,191,563$ \\
\hline HRP & 935 & 1730 & 1248 & 1288 & 1482 & 1502 & 1447 & 2031 & 2340 & 2242 & 2383 & 2398 & 2807 & 3405 & 2648 & 2793 & 3384 & 36,064 & 153.296 \\
\hline
\end{tabular}


The Figure number shows the results predictions by parties, which change from day to day, until a particular date during the campaign. Figure 6 is the predictions through the last campaign day and the actual election results. The Figure number shows the predictions on rounded off winning numbers by each party on the last day of the campaign and the actual results. The prediction errors were, among parties

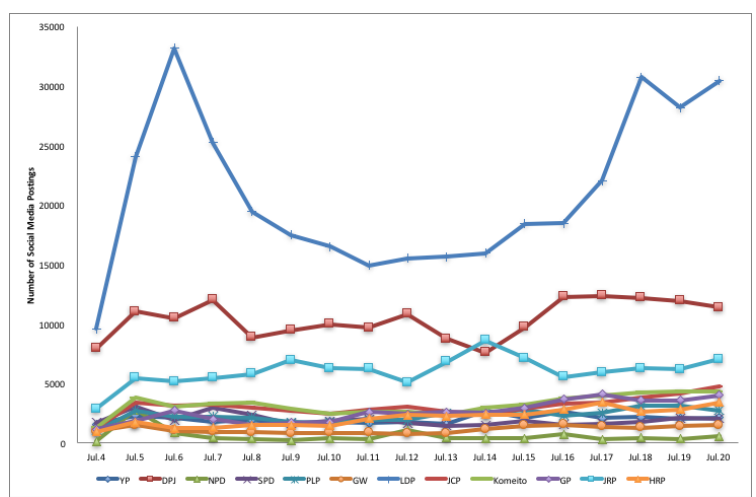

Figure 3. Each party's total number posted by social media

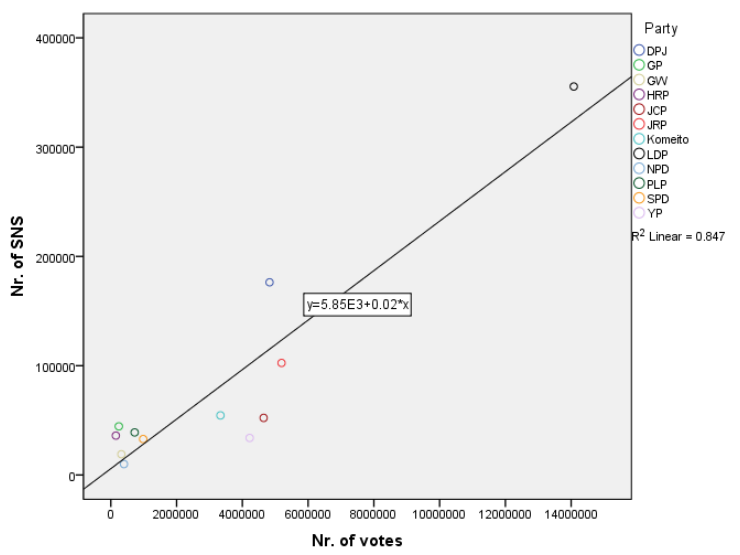

Figure 4. Party-list votes in PR system and social media

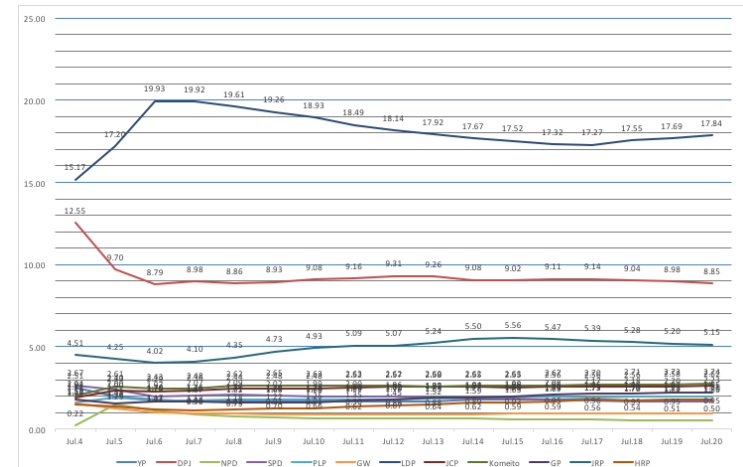

Figure 5. Results predictions in PR system by social media

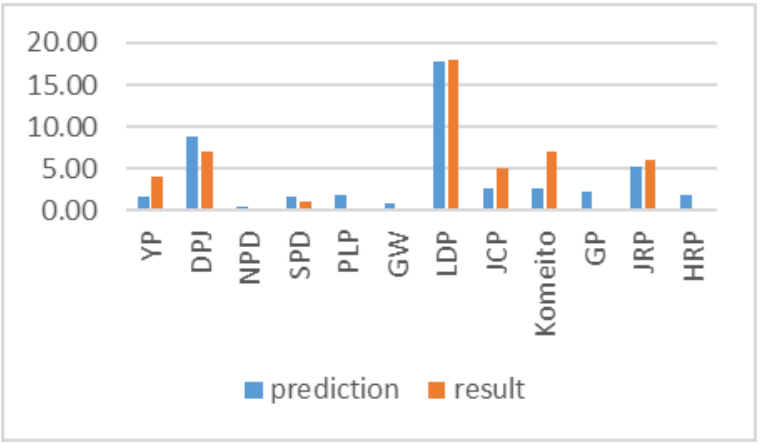

Figure 6. Results predictions in PR system by social media and actual results

identified by party name search, 0 for Liberal Democratic Party of Japan, 2 for Democratic Party of Japan, 4 for Komeito, 1 for Japan Restoration Party, and 2 for Japanese Communist Party. The prediction errors for all parties except Komeito, which holds many organized votes, are within 2 ; therefore, it can be said that the results predictions during the campaign were successfully made. From this, it is concluded that social listening is useful to observe the tendencies of party-list votes in the PR system. Especially, with social listening highly accurate results predictions on party-list votes in the PR system and also real-time results predictions during the campaign are considered possible.

\subsection{Analysis of the $47^{\text {th }}$ Lower House General Election}

At the $47^{\text {th }}$ Lower House general election, unlike in the above Upper House election, the 11 registered parties' official names and official abbreviated names were searched together, and any names similar to those official or official abbreviated names were excluded. The political party "No Supporting Party" was excluded from the beginning since it was unidentifiable, and the "Party for Future Generations" was also excluded after the research because it was found that the party includes many similar words such as "Cars for Future Generations". Re-analysis needs to be performed in the future with a more accurate method. In addition, since the 23th Upper House regular election results showed that the number of postings on Facebook was extremely low compared to Twitter, the analysis for this election focused on Twitter only.

The result was that the data for social listening during the 12 day campaign period is 1,287,982 tweets, and the total number of party-list votes was $51,813,623$ (Table 2 and Figure 7). Some postings were critical of 
Table 2. Each registered party's total number posted during the $4^{\text {th }}$ Lower House election

\begin{tabular}{|l|r|r|r|r|r|r|r|r|r|r|r|r|r|r|}
\hline & \multicolumn{1}{|c|}{ Dec.2 } & \multicolumn{1}{|c|}{ Dec.3 } & Dec.4 & Dec.5 & Dec.6 & Dec.7 & Dec.8 & Dec.9 & Dec.10 & Dec.11 & Dec.12 & Dec.13 & Total & Votes \\
\hline LDP & 28,543 & 24,607 & 40,095 & 32,825 & 34,458 & 35,868 & 39,460 & 37,649 & 37,557 & 37,335 & 41,140 & 55,762 & 445,299 & $17,658,916$ \\
\hline NRP & 363 & 237 & 170 & 171 & 116 & 159 & 96 & 95 & 78 & 75 & 101 & 202 & 1,863 & 16,597 \\
\hline DPJ & 19,958 & 15,786 & 21,535 & 17,870 & 18,922 & 21,622 & 21,734 & 21,862 & 24,073 & 22,613 & 21,637 & 25,699 & 253,311 & $9,775,991$ \\
\hline KOMEI & 8,801 & 7,367 & 9,006 & 9,845 & 9,577 & 8,589 & 11,713 & 10,662 & 10,493 & 8,853 & 8,417 & 11,726 & 115,049 & $7,314,236$ \\
\hline SPD & 3,562 & 3,001 & 2,891 & 2,497 & 2,608 & 2,771 & 2,772 & 3,887 & 3,872 & 3,733 & 3,981 & 5,609 & 41,184 & $1,314,441$ \\
\hline JRP & 5,760 & 5,638 & 6,777 & 5,301 & 5,937 & 6,743 & 7,159 & 6,761 & 7,417 & 6,647 & 6,633 & 10,241 & 81,014 & $8,382,699$ \\
\hline HRP & 1,376 & 130 & 867 & 929 & 904 & 956 & 967 & 975 & 1,014 & 996 & 1,222 & 1,417 & 11,753 & 259,060 \\
\hline PLP & 1,612 & 1,311 & 1,604 & 1,557 & 1,996 & 1,711 & 2,263 & 2,226 & 2,297 & 2,374 & 2,200 & 2,928 & 24,079 & $1,028,721$ \\
\hline JCP & 12,408 & 10,663 & 13,568 & 11,589 & 12,508 & 14,572 & 14,388 & 19,064 & 17,317 & 22,283 & 20,205 & 23,997 & 192,562 & $6,062,962$ \\
\hline
\end{tabular}

parties, and those negative postings were sorted out using the "emotion analysis" tool of Yahoo! JAPAN (at the time of analyzing case 1 (23 ${ }^{\text {rd }}$ Upper House), Yahoo! Japan was not providing the "emotion analysis" services. In case 3 ( $24^{\text {th }}$ Upper House), since we had planned to perform the text mining in our individual way, "emotion analysis" was not used). The numbers in Table 3 and Figure 8 consist of positive postings

only.

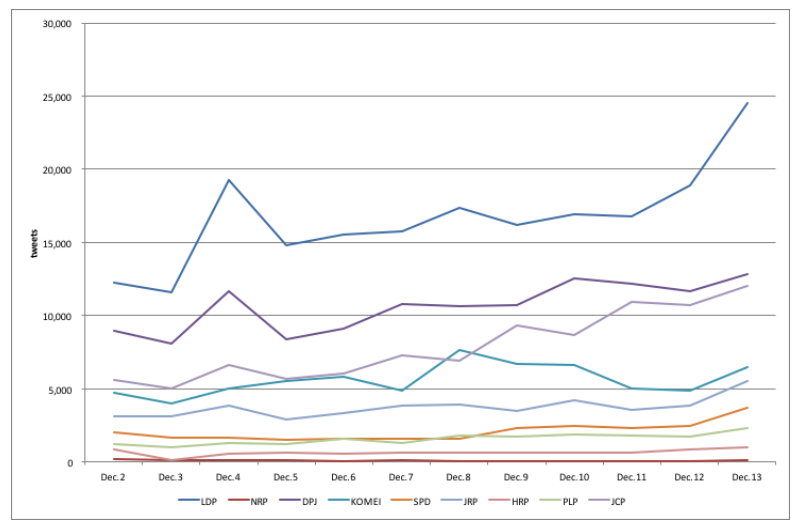

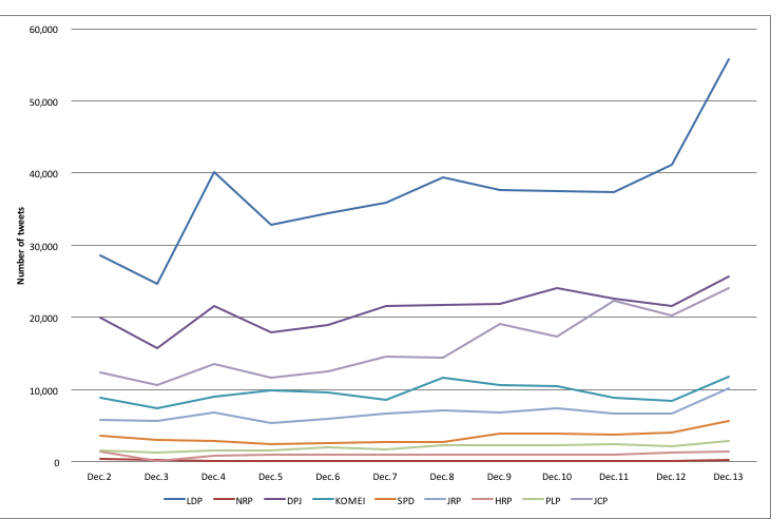

Figure 7. Each party's total number posted by social media

Figure 8. Each party's total number posted excluding negative postings

Table 3. Each registered party's total number posted excluding negative postings during the $4^{\text {th }}$ Lower House election

\begin{tabular}{|c|c|c|c|c|c|c|c|c|c|c|c|c|c|c|}
\hline & Dec.2 & Dec.3 & Dec.4 & Dec.5 & Dec.6 & Dec.7 & Dec. 8 & Dec. 9 & Dec.10 & Dec.11 & Dec.12 & Dec.13 & Total & Votes \\
\hline LDP & 12,273 & 11,565 & 19,246 & 14,771 & 15,506 & 15,782 & 17,362 & 16,189 & 16,901 & 16,801 & 18,924 & 24,535 & 199,856 & $17,658,916$ \\
\hline NRP & 225 & 142 & 136 & 125 & 86 & 121 & 65 & 76 & 76 & 51 & 68 & 127 & 1,298 & 16,597 \\
\hline DPJ & 8,981 & 8,051 & 11,629 & 8,399 & 9,083 & 10,811 & 10,650 & 10,712 & 12,518 & 12,211 & 11,684 & 12,850 & 127,578 & $9,775,991$ \\
\hline KOMEI & 4,753 & 3,978 & 5,043 & 5,513 & 5,842 & 4,896 & 7,613 & 6,717 & 6,611 & 5,046 & 4,882 & 6,449 & 67,343 & $7,314,236$ \\
\hline SPD & 2,030 & 1,681 & 1,677 & 1,498 & 1,591 & 1,552 & 1,552 & 2,332 & 2,478 & 2,314 & 2,468 & 3,702 & 24,876 & $1,314,441$ \\
\hline JRP & 3,110 & 3,101 & 3,863 & 2,863 & 3,325 & 3,844 & 3,937 & 3,516 & 4,228 & 3,589 & 3,847 & 5,530 & 44,752 & $8,382,699$ \\
\hline HRP & 867 & 87 & 555 & 632 & 579 & 669 & 600 & 624 & 659 & 657 & 880 & 1,006 & 7,814 & 259,060 \\
\hline PLP & 1,225 & 1,009 & 1,283 & 1,199 & 1,617 & 1,317 & 1,833 & 1,759 & 1,907 & 1,828 & 1,738 & 2,313 & 19,028 & $1,028,721$ \\
\hline $\mathrm{JCP}$ & 5,584 & 5,012 & 6,648 & 5,679 & 6,004 & 7,286 & 6,906 & 9,341 & 8,659 & 10,919 & 10,709 & 11,999 & 94,744 & $6,062,962$ \\
\hline
\end{tabular}

As Figure 7 and 8 show, Liberal Democratic Party of Japan, Democratic Party of Japan and Japanese Communist Party are tweeted in descending order. The total number of Tweets during the campaign and the total party-list votes in 11 constituencies (Hokkaido, Tohoku, Kitakanto, Minamikanto, Tokyo, Hokurikusinetsu, Tokai, Kinki, Chugoku, Shikoku,
Kyushu) in the PR system are shown in Table 3 (With Yahoo! Japan's real-time search certain areas of Japan cannot be specified; therefore, those twitter postings were analyzed from the total number of votes each party gained and the number of tweets collected from all over Japan). The correlation of these two values is shown in Figure 9. 
As the Figure shows R2 is 0.880, and Pearson correlation coefficient is 0.938 which is $1 \%$ level and is significant (both sides); thus a strong correlation between the number of tweets containing party name and the total party-list votes in each constituency in the PR system is found.

Figure 10 shows, among postings during the campaign, each party's total number posted is proportioned by 180 seats involved in the PR system until a particular date described in the Table.

Figure 11 shows the results predictions through the last day of the campaign and the actual election results. The predictions, among parties identified by party name search, on rounded off winning numbers by each party on the last day of the campaign and the actual results are shown in the Figure, and prediction errors were 7 for Liberal Democratic Party of Japan, 4 for Democratic Party of Japan, 5 for Komeito, 7 for Japan Restoration Party, and 9 for Japanese Communist Party. The prediction errors are larger than those at the 23rd Upper House regular election. Those errors are considered to be caused by the complicated Lower House electoral system, under which the number of seats in the Lower House is over three times the number of seats in the Upper House, candidates win by sekihairitsu (best loser calculation), some parties do not list candidates in the PR system in some of the 11 constituencies, etc., and further examination is needed.

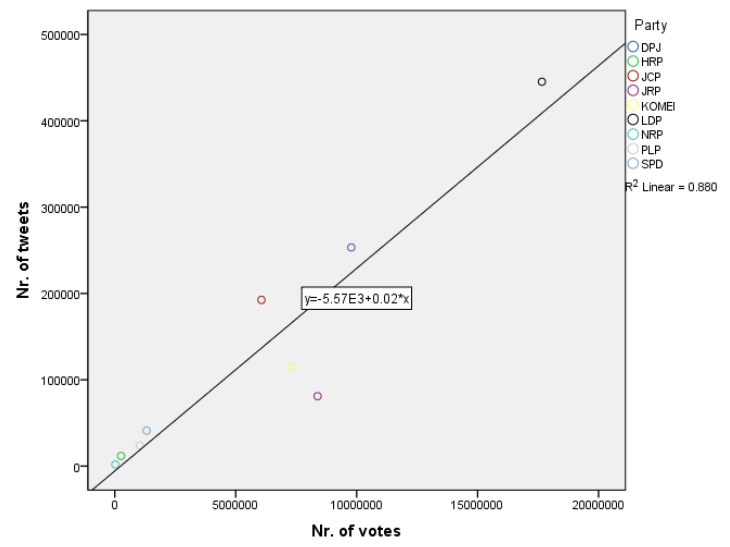

Figure 9. Party-list votes and the number of tweets

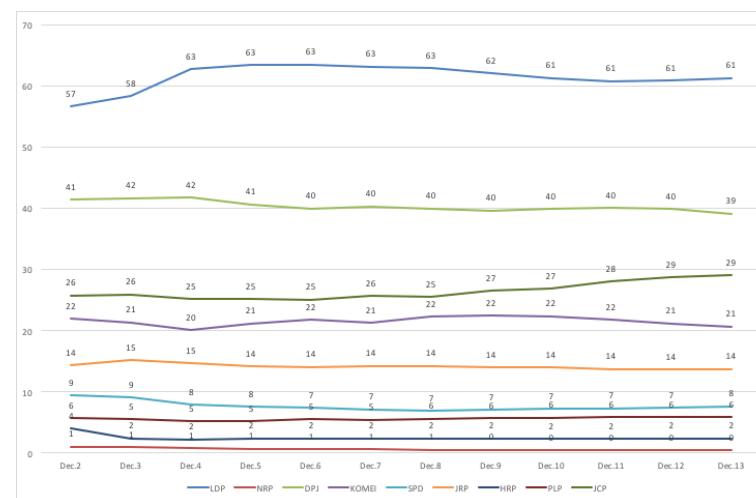

Figure 10. Results Predictions in PR System by Social Media

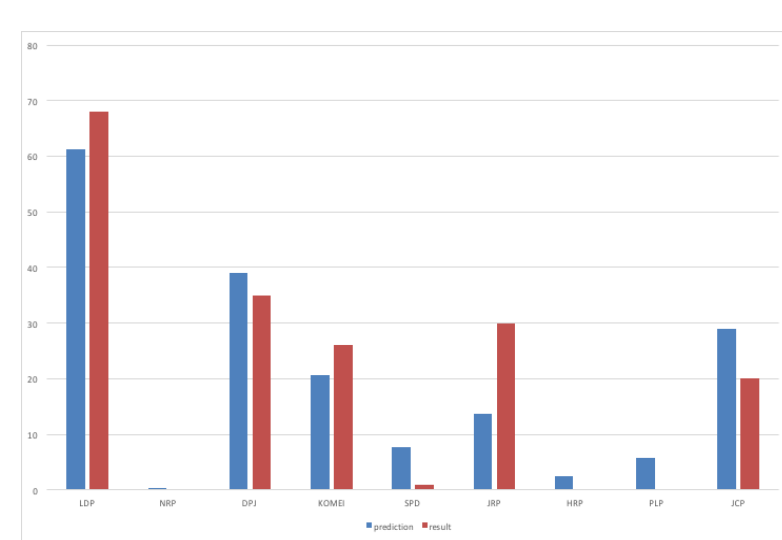

Figure 11. Results predictions in PR System by social media and actual results

\section{Analysis of the $24^{\text {th }}$ Upper House General Election by Social Listening}

The $24^{\text {th }}$ Upper House general election was announced on June 22 and held on July 10, 2016. Its analysis was made in the same manner as the $47^{\text {th }}$ Lower House general election described in the previous section. The 12 registered parties' official names and official abbreviated names were searched together, and any names similar to those official or official abbreviated names were excluded. The political party "No Supporting Party" was excluded from the beginning since it is unidentifiable.

The data used for social listening during the 19 day campaign period is $1,777,724$ tweets, and the total party-list votes was 56,007,353 (Table 4 and Figure 12). The number of party names tweeted are Liberal Democratic Party of Japan, Japanese Communist Party and Democratic Party of Japan in descending order as shown in the Table.

The total number of tweets during the campaign and the total party-list votes in the PR system are shown in Table 4. The correlation of these two values 
is shown in Figure 13, and the Figure shows that R2 is 0.891, and Pearson correlation coefficient is 0.944 which is $1 \%$ level and is significant (both sides); thus a strong correlation between the number of tweets that contained a party name and the total number of partylist votes in each constituency in the PR system is found. Figure 14 shows, among postings during the campaign, each party's total number tweeted until a specified date was proportioned by 48 seats involved in the PR system.

Table 4. Each registered party's total number posted during the $24^{\text {th }}$ Upper House election

\begin{tabular}{|c|c|c|c|c|c|c|c|c|c|c|c|c|c|c|c|c|c|c|c|c|c|}
\hline & n.22 & \begin{tabular}{l|l|} 
n.23 \\
\end{tabular} & .24 & n.25 & n. 26 & 1.27 & 1.28 & n.29 & Jun.30 & a.1 & ul.2 & Jul.3 & 1.4 & 1.5 & Jul.6 & Jul.7 & Jul. 8 & ul. 9 & ul.10 & otal & \\
\hline LDJ & 538 & 232 & 342 & 508 & 24,459 & 703 & & 280 & 446 & 787 &, 068 & 29,865 & 29,581 & 37,151 & 40,998 & 36,696 & 38,962 & 63,885 & 8,056 & 79,951 & \\
\hline & & & & & & & & & & & & & & & & & & & & & \\
\hline$P$ & & & & & 14 & & & & 39 & & & & & & & & & & & & \\
\hline m & 07 & & & 24 & 204 & 08 & 93 & 19 & 304 & 45 & 42 & 568 & 304 & 312 & 867 & 971 & 299 & 11,073 & 842 & 22 & 60 \\
\hline D & & & & & 895 & & & & 067 & 91 & & & 757 & 840 & 20 & 643 & 300 & 20 & 743 & & \\
\hline $\mathrm{RP}$ & 307 & 598 & 393 & 39 & 994 & 596 & 308 & 182 & 0,083 & 191 & 556 & 437 & 046 & 157 & 637 & 7,679 & ,403 & .587 & 4,170 & 963 & \\
\hline$/ \mathrm{P}$ & & & & & 97 & 74 | & & 0 & 22 & 71 & 350 & 284 & 316 & 278 & 8 & 583 & 587 & 78 & 788 & 1 & 06 \\
\hline HRP & 3 & 713 & & & 490 & 494 & 691 & 5 & 57 & 877 & 287 & 844 & 133 & 834 & 853 & 1,677 & 344 & 238 & 724 & & \\
\hline NRP & 11 & 27 & 5 & 8 & 398 & \begin{tabular}{l|l}
405 \\
\end{tabular} & 330 & 444 & 473 & 629 & 345 & 428 & \begin{tabular}{ll|}
473 \\
\end{tabular} & 450 & 457 & 709 & .455 & 1,064 & 996 & \begin{tabular}{l|l|}
2,227 \\
\end{tabular} & 580,653 \\
\hline PJK & 088 & 772 & 016 & 1,050 & 1,184 & 920 & 84 & 728 & 569 & 709 & 794 & 1,219 & .026 & ,470 & 630 & .034 & .046 & 587 & 116 & 862 & 4,024 \\
\hline LP & 126 & 803 & 054 & 95 & 898 & .006 & 118 & 1,253 & 943 & 1,115 & .186 & 1,512 & 1,473 & 1,810 & 1,581 & 1,732 & 2,229 & 3,217 & 1,563 & 26,514 & $1,067,300$ \\
\hline
\end{tabular}

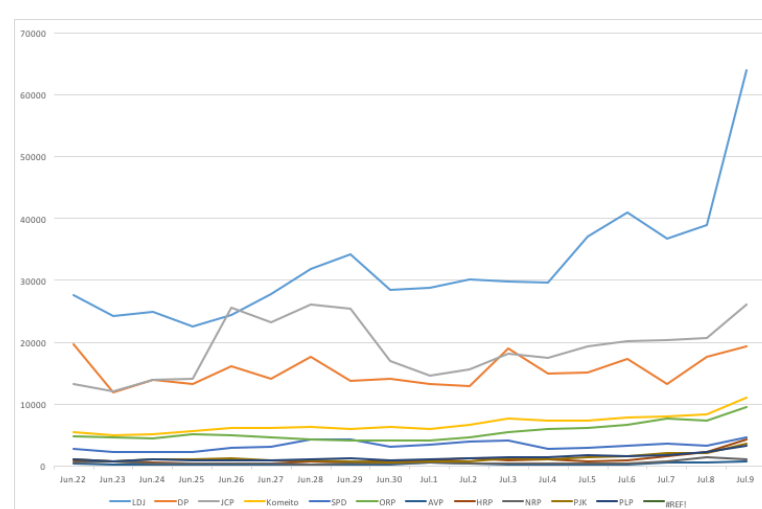

Figure 12. Each party's total number posted by social media

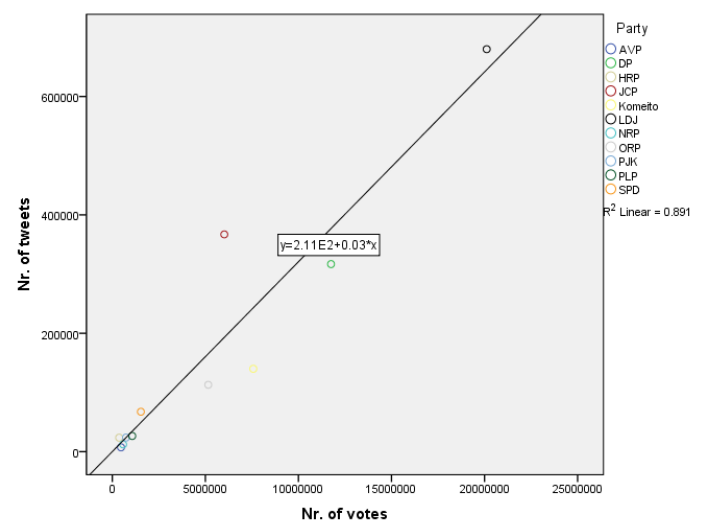

Figure 13. Party-list votes and the number of Tweets

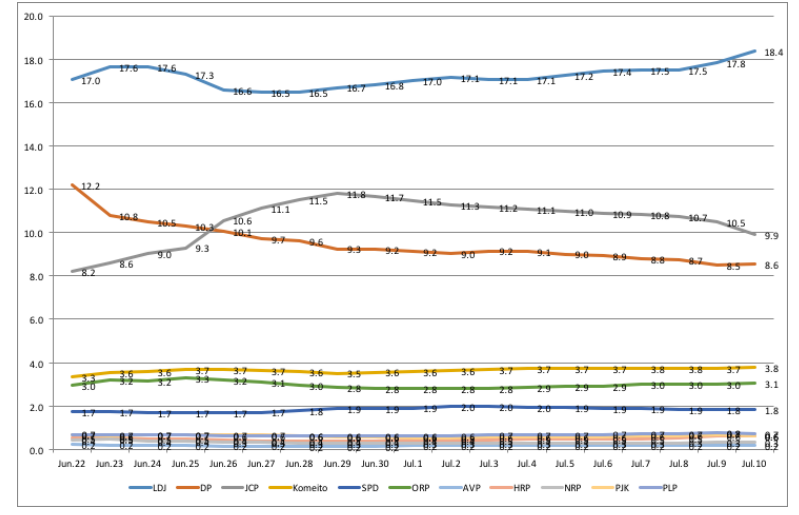

Figure 14. Results predictions in PR system by social media

The results predictions on each party until a specified date are made in the Figure. The results predictions through the last day of the campaign and the actual results are shown in Figure 15. The Figure number shows the predicted rounded off winning numbers by each party on the last day of the campaign, and there is a prediction error of 1 for Liberal Democratic Party of Japan, among parties identified by party name search, but an error for the Japanese Communist Party was wider because the same individuals tweeted many times. 


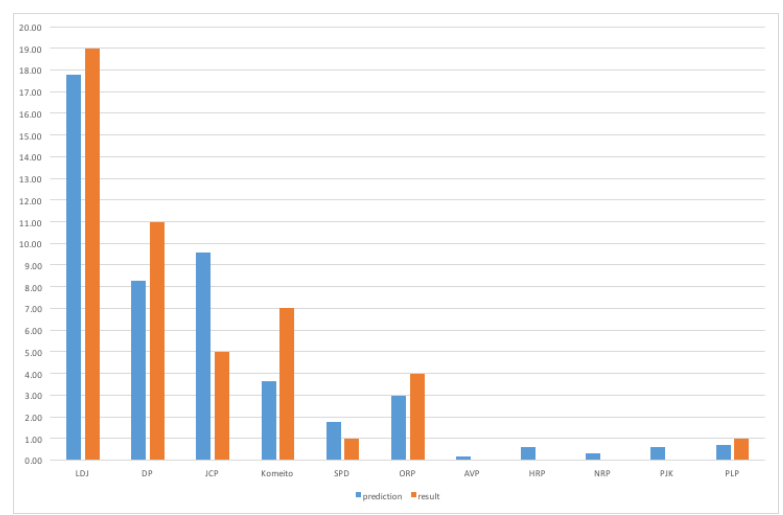

Figure 15. Results predictions in PR system by social media and actual results

\section{Conclusion}

Election campaigns utilizing social media have been increasingly used all over the world. In Japan campaigns using social media became available as of the Upper House regular election in July 2013, and political parties, candidates and voters are able to post comments about elections via social media. In contrast with the U.S. where Edmund Brown Jr. first used emails for the presidential election campaign in 1992, Japan's history of Internet campaigning is not long, and current regulations do not allow the "Obama-style" campaign. However, social listening using Twitter was valid for election analysis thanks to the enormous amount of tweets created by the active use of Twitter in Japan. The analysis of national elections by Goto (2015) and the $24^{\text {th }}$ Upper House regular election in 2016 analyzed found that predictions of the results were not possible for small constituencies due to the scarce number of postings and also for candidates who rely on organized votes. In addition, from the fact that the number of postings for the Upper House regular election in 2013 doubled in 2016, which were 956,268 and $1,777,724$ respectively, the accuracy of predictions will be increased in the future.

However, after the $47^{\text {th }}$ Lower House election the number of postings by the same individuals has rapidly increased on social media. Although at a public opinion survey conducted by CNN on the second U.S. presidential debate, Hillary Clinton was considered winner with $51 \%$ votes (34\% for Trump), the Internet voting conducted by TIME shows $87 \%$ for Trump and $13 \%$ for Clinton ${ }^{[12]}$, and it was pointed out that there was a possibility that Trump supporters repeatedly clicked for him in the survey. From that point, frequencies and contents of postings need to be carefully examined for more accurate predictions, in addition to the analysis of election trends using text mining. Furthermore, the use of social media by a wider range of age groups in the future adds to this study's significant meaning. A future task is to increase the accuracy of predictions by sorting out postings by the same individuals, and also to analyze election voting tendencies. The analysis of duplication of postings by the same individuals has been initiated, and the report will be available in the near future. In this study, predictions were made using a simple weighting method and the number of postings. However, our goal is to provide a theory as, for example, Harris Interactive developed with their original model theory to make predictions for the 2000 U.S. presidential election, which was incomparably more precise compared to that by the Gallup Organization.

\section{References}

[1] Maejima Kazuhiro, "Election Campaign Tactics Social Media Changes" Election Internet Changes, Keio University Press Inc., Japan, 2011, pp.27-49 (Japanese)

[2] Gordon MacMillan (2010) "Twitter Hires Current TV Strategist for Media Role"

<http://www.campaignlive.co.uk/article/twitter-hires-currenttv-strategist-media-role/981229?src_site=mediaweek $>$ April 21,2017

[3] Goto Hisaki, "Socio-Informatics and Business: Social Media and Data-Intensive Science" Socio Informatics Vol. 1 Number 2, Japan, 2012, pp. 27-35 (Japanese)

[4] Takeda Koichi, Ide Tsuyoshi, "Perspectives on Big Data Processing -Changing Trends in Data Analysis Technology-“ Pro Vision No. 72, Japan, 2012, pp. 40-45 (Japanese)

[5] <https://linecorp.com/ads/pdf/89F3A5E6-D543-11E5AF0A-B27B5BCB9FFE> April 21,2017

<https://twitter.com/TwitterJP/status/793649186935742465> April 21,2017

<http://www.nikkei.com/article/DGXLASDZ15HML_V10C 17A2000000/?dg=1\&nf=1> April 21,2017

[6] IT Media (2015) "The Japanese insane Love of Twitter" Twitter opened its development base in Japan. Propose its utilizing method"

<http://www.itmedia.co.jp/news/articles/1509/04/news086.ht ml> April 21,2017

[7] Andranik Tumasjan, Timm O. Sprenger, Philipp G. Sandner, and Isabell M. Welpe "Predicting Election with Twitter: What 140 Characters Reveal about Political Sentiment" Proceedings of the Fourth International AAAI Conference on Weblogs and Social Media,2010, pp. 178-185

[8] Andreas Jungherr, Pascal Jürgens, and Harald Schoen, "Why the Pirate Party Won the German Election of 2009 or The Trouble With Predictions" Social Science Computer Review 30(2),2012, pp. 229-234 
[9] Nasuno Kaoru, and Matsuo Yutaka, "Predicting Japanese General Election in 2013 with Twitter: Considering Diffusion of Candidates' Tweets" IECE Technical Report. NLC, Natural language understanding and mode ls of communication No. 11113 (338), Japan, 2013, pp.25-28 Nasuno Kaoru, and Matsuo Yutaka, "Considering Diffusion of Candidates' Tweets" Papers for the 28th Annual Conference of the Japanese Society for Artificial Intelligence, Japan, 2014, pp. 1-4 (Japanese)

[10] Yoshimi Kenji, "Usage Tendencies of Social Media by Each Political Party during Election Campaign — A Study on Twitter Use in the 47th General Election - " Socio Informatics, Vol. 4 Nr. 3, Japan, 2016, pp. 16-29 (Japanese)

[11] Goto Hisaki, "A study of Elections using Social Media and the Internet" Journal of Japan Society for Information and Management, Vol. 35 number 4, Japan, 2015, pp.34-42 (Japanese)

[12] Time (2016)“Presidential Debate Poll” <http://time.com/money/4524312/second-presidentialdebate-vote-poll/> April 21,2017 